NASA Technical Memorandum 102044

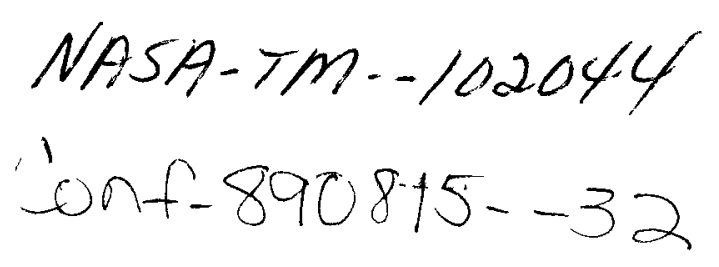

\title{
Results From Baseline Tests of the SPRE I and Comparison With Code Model Predictions
}

James E. Cairelli and Steven M. Geng

National Aeronautics and Space Administration

Lewis Research Center

Cleveland, Ohio

and

Robert C. Skupinski

Sverdrup Technology, Inc.

NASA Lewis Research Center Group

Cleveland, Ohio

Prepared for the

24th Intersociety Energy Conversion Engineering Conference cosponsored by the IEEE, AIAA, ANS, ASME, SAE, ACS, and AIChE Washington, D.C., August 6-11, 1989

\section{DISCLAIMER}

This report was prepared as an account of work sponsored by an agency of the United States Government. Neither the United States Government nor any agency thereof, nor any of their employees, makes any warranty, express or implied, or assumes any legal liability or responsibility for the accuracy, completeness, or usefulness of any information, apparatus, product, or process disclosed, or represents that its use would not infringe privately owned rights. Reference herein to any specific commercial product, process, or service by trade name, trademark, manufacturer, or otherwise does not necessarily constitute or imply its endorsement, recommendation, or favoring by the United States Government or any agency thereof. The views and opinions of authors expressed herein do not necessarily state or reflect those of the United States Government or any agency thereof. 


\section{DISCLAIMER}

This report was prepared as an account of work sponsored by an agency of the United States Government. Neither the United States Government nor any agency Thereof, nor any of their employees, makes any warranty, express or implied, or assumes any legal liability or responsibility for the accuracy, completeness, or usefulness of any information, apparatus, product, or process disclosed, or represents that its use would not infringe privately owned rights. Reference herein to any specific commercial product, process, or service by trade name, trademark, manufacturer, or otherwise does not necessarily constitute or imply its endorsement, recommendation, or favoring by the United States Government or any agency thereof. The views and opinions of authors expressed herein do not necessarily state or reflect those of the United States Government or any agency thereof. 


\section{DISCLAIMER}

Portions of this document may be illegible in electronic image products. Images are produced from the best available original document. 


\section{RESULTS FROM BASELINE TLSTS OF THE SPRE I AND COIIPARISON \\ WITH CODE MODEL PREOILTIONS}

James $E$ Cairell1 and Steven $M$ Geng

National Aeronautics and Space Administration

Lewis Research Center

Cleveland, Oh10 44135

and

Robert C Skupinski

Sverdrup Technology, Inc

NASA Lewis Research Center Gioup

Cleveland, Oh10 44135

\section{ABSTRACT}

The Space Power Research Englne (SPRE), a free-piston Stirling engine with linear alternator, is being tested at the NASA Lewis Research Center as part of the Civil Space Technology Initlative (CSTI) as a candidate for high capacity space power This paper presents results of baseline engine tests at design and off-design operating conditions The test results are compared with code model predictions

\section{INTRODUCTION}

The work reported in this paper is funded by the NASA Civil Space Technology Initiative (CSTI) Because of its high thermal efficiency potential. Stirling is a candidate for high capacity power for space systems in the late 1990's and into the next century since the free-piston Stirling is a relatively immature technology, the SPRE engines were bullt to serve as research tools to evaluate the engine in its initial form and to provide a test bed for component technology development This report presents a portion of the test data obtained at the NASA Lewis Research Center with the SPRE I in its original or baseline configuration Computer predictions using the HFAST code are also presented for comparison

\section{TEST OBJECTIVES}

1 To establish a reference set of data at various operating conditions over a range of temperature ratios from 16 to 24 and mean pressures from 50 to $150 \mathrm{MPa}$ These data are intended for the validation of computer codes and for comparison with future test data

2 To determine the engine performance sensitivity to variations in operating conditions, particularly its sensitivity to operating temperatures

3 To chech out and tune the facility systems SPRE I TEST EQUIPMENT

The SPRE I 15 one of two engines that were designed and bullt by Mechanical Technology, Inc.
(MTI) of Latham NY, under contract with NASA The second englne, enlains at MITI These engines were bullt by plitting the original space Puver Demonstrator Engine (SPDE) in halves and modifying the open hot ends of the cylinders by adding closure heads References 1 to 3 describe the SPDE program and engine test results The photograph in Fig I shows the SPRE I installed in the NASA Lewis test facility fig 2 is a cross section drawing of the SPRE showing its major paits Because of the limited amount of space avallable in this paper, only the following brief description of the test arrangement is presented

Heat is supplied to the engine by circulating molten salt through the engine heater Waste heat is removed from the engine by circulating water through the cooler Helium is used as the working gas The engine produces electrical power by means of a linear alternator diven directly by the power piston The electrical power is absorbed by an electical resistance load, which contiols the alternator output voltage and resulting piston stroke The SPRE I engine and test facility, including instiumentation, are described in reasonable detall in [4]

\section{GENERAL TEST PROCEDURES}

Before starting, the engine was piessur ized with hellum working gas to $50 \mathrm{MPa}$, the cooling water flow als set to about 1211 ter/sec, the salt flow was established at about 171 iter/sec and the engline $s$ heater was preheated unt 11 the absolute temperature ratio of the heater to cooler metal temperatures was about 16 The engine was then started using $60 \mathrm{~Hz}$ electrical power After the englne started, the mean pressure was ralsed to $75 \mathrm{MPa}$, and data were taken at temperature ratios of $; 7,18$, and 20 At each tempes ature iatio data were taken at $5,6,7,8,9$, and $10 \mathrm{~mm}$ piston amplitudes (half stroke) While holding the temperature 1 atio at 20 data were also taken at $50,75,100,125$, and $150 \mathrm{MPa}$ for the prevlously mentioned piston amplitudes At $15 \mathrm{MPa}$ data were also taken at 1079 and $1107 \mathrm{mnl}$ (nomlnal design maximum piston amplitude 15100 min) to determine the actual limit or piston amplitude and output power at $15 \mathrm{MPa}$ and a temperature ratio of 
20 Data measurements at $15 \mathrm{MPa}$ and at other temperature ratios were planned However, while preparing to make another test with the engine to complete the data set, the alternator plunger was severely damaged in an unfortunate accident considerable time has been required to iepair the plunger and to solve a number of other problems At this writing, englne data have not been measured at $15 \mathrm{MPa}$ for temperature ratios other than 20

\section{CODE PREDICTIONS}

The Stirling engine performance code used to generate the predicted data in the plots shown in this report was HFAST, version 102 HFAST was written by Mechanical Technology, Inc, (MTI) under MTI internal R\&D funding The major development of HFAST began in 1985 and continued through 1987 The HFAST code is currently being further improved by MTI under contract with NASA HFAST can simulate both free-piston and kinematic Stirling engines HFAST assumes that the solution of the governing conservation equations aie harmonic functions of time The solution is then found by solving a system of nonlinear, algebralc equations rather than a system of differential equations

The SPRE working space was divided into nine control volumes for the computer simulation as shown in $\mathrm{Fig} 3$ A single control volume was used to model each the displacer appendix gap, expansion space, heater, cooler, and primary compression space Two control volumes were used to model each the regenerator and the cooler-to-compression-space connecting ducts This setup neglected the second compression-space volume (see Fig 2), which exists at the cold end of the displacer since HFAST is a one-dimensional code, the addition of the second compression-space volume to the computer model probably would not have had a significant effect on the predictions When a second compression-space volume was added to the NASA Lewis SPRE code, which is a onedimensional code, the effect on the code predictions was insignificant

The actual measured piston and displacer motions, frequencies, mean pressures, salt and water flows, and temperatures were used as inputs to the HFAST code Predictions were made for compression-space pressure variations, piston PV power, heater and cooler heat flows, piston PV efficiency, and other parameters for comparison to SPRE I measured data

\section{RESULTS}

The initial SPRE I data presented earlier [4] differ from the data presented in this paper The differences are due to a change in the calculation for the cooler water-side tube wall temperature After reviewing the range of Prandtl and Reynolds numbers existing in the SPRE cooler, it was determined that the water-side heat-transfer correlation (see [5], Eq 9 108b) used during the initial testing was not appropriate The predicted temperature drop between the tube wall temperature and the bulk water temperature tended to be too high
Therefore the calculated cooler wall temperature was higher than the actual cooler wall temperature, and the calculated wall temperature ratio between the heater tubes and the cooler tubes was lower than the actual temperature ratio The cooler, water-side heat-transfes correlation was replaced with a new correlation [6] The revised calculation for cooler tube outside-wall temperature has been used for all subsequent tests

Figure 4 shows the wal1 temperature ratio determined using the revised calculation versus piston amplitude for the data taken at a wall temperature ratio of 20 presented in [4] For comparison, the calculated wall temperature ratios for the SPRE data reported in this paper ale also shown Although the original data was intended to be at a temperature ratio of 20 , the temperature ratios were actually higher, approaching 2 l at $9 \mathrm{~mm}$ piston amplitude

Unless otherwise stated the data plots discussed below are for a temperature ratio of 20

The measured operating frequencies as a function of engine mean pressure at a temperature ratio of 20 for 60,80 and $100 \mathrm{~mm}$ piston amplitudes are shown in figure 5 The frequency varies approximately in proportion to the square root of the mean pressure from about 60 to

$100 \mathrm{~Hz}$ The frequency is affected slightly by the piston amplitude, tending to drop as piston amplitude increases At $15 \mathrm{MPa}$ mean pressure the frequency drops $14 \mathrm{~Hz}$ when the piston amplitude is increased from 6 to $10 \mathrm{~mm}$ This is most likely due to an inciease in effective system damping caused by gas flow losses increasing at a higher rate than the power as the piston amplitude is increased

The piston PV power (rate of work performed on the power piston by the compression-space gas) versus piston amplitude is shown in figure 6 The piston PV power is based on the operating frequency and the integial of $P d V$ using first order harmonic expressions for the compression-space pressure amplitude and phase angle relative to the piston motion, piston amplitude, and piston area Data are shown for mean pressures of 150,100 , and $50 \mathrm{MPa}$ The PV power varies nearly inearly with increasing piston amplitude and also with increasing mean pressure raised to about the 15 power The measured power tends to be lower than the predicted power At $15 \mathrm{MPa}$ the measured power is 65 to 8 l percent lower than the predicted values The difference between predicted and measured power at $10 \mathrm{MPa}$ tends to increase with piston amplitude from 42 to 70 percent At $5 \mathrm{MPa}$ the difference also increases fiom 60 to 94 percent as the piston amplitude increases At $15 \mathrm{MPa}$ and a design maximum piston amplitude of $10 \mathrm{~mm}$, the measured PV power was $1194 \mathrm{~kW}$ and the predicted power at that condition was $1299 \mathrm{~kW}$ The maximum PV power achieved by the engine was $1289 \mathrm{~kW}$ at an overstroke piston amplitude of $1107 \mathrm{~mm}$

The effect of temperature ratio on PV power is shown in Fig 7 The PV power at $75 \mathrm{MPa}$ mean pressure is plotted against temperature ratio for 
piston amplitudes of 10 and $5 \mathrm{~mm}$ The $\mathrm{PV}$ power tends to vary nearly linearly with increasing temperature ratio The code predictions tend to be greater than the measured data by 13 to 68 percent The percentage difference increases with increasing temperature ratio and with increasing piston amplitude

The compression space pressure amplitude versus piston amplitude are shown in $\mathrm{Fig} 8 \mathrm{All}$ the measured data falls within about 2 percent of the predicted values

Figure 9 shows the compression space pressure phase angle versus the piston amplitude The phase angle was measured with respect to the piston amplitude The negative sign indicates that the pressure lags the piston motion The trends in the measured data are similar to the predictions The pressure phase angle magnitude tends to decrease as the piston amplitude increases, with the slope being greater at $15 \mathrm{MPa}$ However, the measured phase angles are smaller than the predicted angles (well outside the error bands) The greatest difference is about $095^{\circ}$ at $5 \mathrm{MPa}$ with $9 \mathrm{~mm}$ piston amplitude The smaller pressure phase angles account for most of the difference between measured and predicted PV power

The piston PV efficiency versus the piston amplitude is shown in figure 10 for 5 and $15 \mathrm{MPa}$ mean pressure The PV efficiency was calculated by dividing the piston PV power by the heat flow to the heater The PV efficiency is relatively insensitive to piston amplitude and mean pressure The measured values vary only from about 175 to 226 percent over the full range of plston amplitude and mean pressure At $5 \mathrm{MPa}$ the efficiency tends to increase as the piston amplitude increases, as predicted It was 037 percentage points higher at $5 \mathrm{~mm}$ and tended to fall below the predictions by up to 084 points as the piston amplitude increased The code predicts the efficlency at $15 \mathrm{MPa}$ to be maximum at $5 \mathrm{~mm}$ and to decrease as the piston amplitude increases The measured data at $15 \mathrm{MPa}$ fall below the predictions and tends to peak at about $8 \mathrm{~mm}$ The difference between measured and predicted efficiency at $15 \mathrm{MPa}$ is 246 percentage points at $5 \mathrm{~mm}$ and decreases to about 11 points at 9 and $10 \mathrm{~mm}$

Figure 11 shows the measured PV efficiency data versus piston PV power for all the data taken at temperature ratio $=20$ This figure very dramatically shows that the SPRE PV efficiency is nearly constant over more than an order of magnitude range of PV power The highest PV efficiency occurred at $75 \mathrm{MPa}$ over a range of 77 to $51 \mathrm{~kW}$, varying only from 2122 to 2264 percent

Figure 12 shows the PV efficiency versus temperature ratio at $75 \mathrm{MPa}$ for 10 and $6 \mathrm{~mm}$ piston amplitude As expected the PV efficiency increases with temperature ratio At $10 \mathrm{~mm}$ piston/amplitude the measured data are very close (within \pm 05 peicentage point) to the predictions At $6 \mathrm{~mm}$ the measured data are 164 to 105 points higher than the predictions and the difference decreases as the temperature ratio increases
In Fig 13 the heat input rate to the heater is shown versus piston amplitude The measured heat flow varies nearly linearly with piston amplitude and with mean pressure to about the 15 power The measured data generally agrees closely with the predictions At $15 \mathrm{MPa}$ the measured data ranges from 46 percent higher than the prediction at $5 \mathrm{~mm}$ to 25 percent lowe than prediction at 10 $\mathrm{mm}$ At $10 \mathrm{MPa}$ the measured data ranges from 7 to 23 percent lower and at $5 \mathrm{MPa}$ the measured data ale 81 to 57 percent lower

The cooler heat rejection rate is shown in Fig 14 versus the piston amplitude The cooler heat flow also varles nearly linearly with piston amp' 1 tude and with the mean pressure to about the 15 power At $15 \mathrm{MPa}$ the SPRE data were 06 to 265 peicent lower than predicted At $10 \mathrm{MPa}$ the measured data ranged fronil 35 percent lower to 07 percent higher than the predictions And at $5 \mathrm{MPa}$ the measured data were 04 to 89 percent lower than the predicted values

The expansion space mean gas temperature versus piston aliplitude is shown in fig 15 The measured temperatures are lower than the predicted temperatures At $15 \mathrm{MPa}$ the measured temperatures are 07 to $72^{\circ}$ lower than predicted At $10 \mathrm{MPa}$ the SPRE data were 04 to $101^{\circ}$ lower And at $5 \mathrm{MPa}$ the measured values were 31 to $218^{\circ}$ lower than predicted The difference tends to decrease as mean pressure and piston amplitude increase, which suggests possible measurement error due to conduction along the theimocouples or differences between the heat transtel dependent mear value measured by the thermocouples and the time averaged mean gas temperature calculated by the code Since it was not practical to maintain the salt temperature within small limits while maintaining constant wall temperature ratio, the expansion space temperature variation does not refiect a tiend due to the engine but rather the variation in operating conditions

Figule 16 shows compression space mean gas temperature as a function of piston amplitude The measured temperatures are lower than the predicted values At 15 and $10 \mathrm{MPa}$ the measured data ale within $2^{\circ}$ of the predicted values At $5 \mathrm{MPa}$ the measured data were lower by 37 to $6{ }^{\circ} \mathrm{C}$ The implications of the differences between measured and predicted temperatures are the same as those for the expansion space temperatures

\section{CONCLUDING REMARKS}

The measured data appear to agree falrly well with the HFAST code predictions The piston PV power agrees within 10 peicent and PV efficiency agrees within about 25 percentage points The heat to the heater and heat rejected by the cooler dgree within about 9 percent The trends in measured data generally follow the same trends as the code preaictiuns The relatively large difference (nuch larger than the data eiror band) between measured and predicted compression space pressure phase angle and resulting lower measured PV power and efficiency as well as the expansion space and compiession space temperatures tending always to 
be lower than the code predictions suggest possible measurement or measurement interpretation errors and that the code may not accurately represent or recognize some of the losses, heat-transfer, and aerodynamic phenomena associated with oscillating flow. The code also does not account for effects of gas bearing flows and mass transport between volumes of the engine.

The large estimated error bands on PV power and efficiency, heat input and heat rejected are due primarily to the uncertainty in the compression space pressure amplitude and delta temperature measurements for the heater and cooler. Although the engine data suggests that the actual error may be somewhat less than the current estimates, there is a need to improve the accuracy of these measurements through improved setup and calibration or possibly by using alternative techniques with inherently less error.

Further improvement in free-piston Stirling engine performance will depend heavily upon code models to guide hardware design. A major element in the NASA Stirling activities is loss understanding. This effort is being done primarily through contracts and college grants to investigate and model the effects of oscillating flow on viscous losses and heat transfer in the various components of the Stirling cycle as well as losses in gas springs. As they become available, the results of the loss understanding work and experimental engine tests will be integrated into the engine codes.

\section{REFERENCES}

[1] G.R. Dochat, "Free-Piston Stirling Engines for Space Power," in Twenty-Second Automotive Technology Development Contractor's Coordination Meeting, Society of Automotive Engineers, Warrendale PA, 1984, pp. 209-213.

[2] J.G. S1aby, "Overview of the 1985 NASA Lewis Research Center SP-100 Free-Piston Stirling Engine Activities," NASA TM-87028, DOE/NASA/1005-5, 1985

[3] J.G. Slaby, "Overview of Free-Piston Stirling Technology at the NASA Lewis Research Center," NASA TM-87156, DOE/NASA/1005-7, 1985.

[4] J.E. Cairelli, "SPRE I Free-Piston Stirling Engine Testing at NASA Lewis Research Center," NASA TM-100241, 1988.

[5] M.N. Ozisik, Heat Conduction, Wiley, New York, 1980.

[6] S. Whitaker, "Forced Convection Heat Transfer Correlations for Flow in Pipes, Past Flat Plates, Single Cylinders, Single Spheres, and for Flow in Packed Beds and Tube Bundles," AIChE J., vol 18, no. 2, pp. 361-371, Mar. 1972

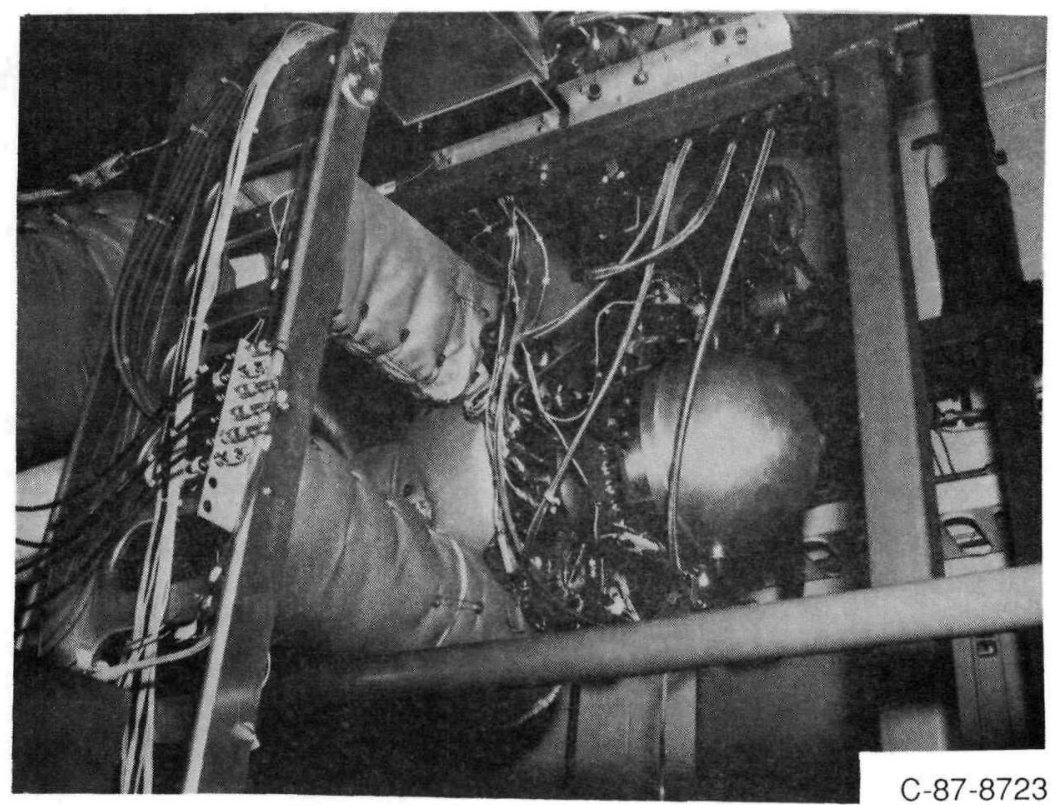

Fig. 1. - SPRE I installed in the NASA facility 


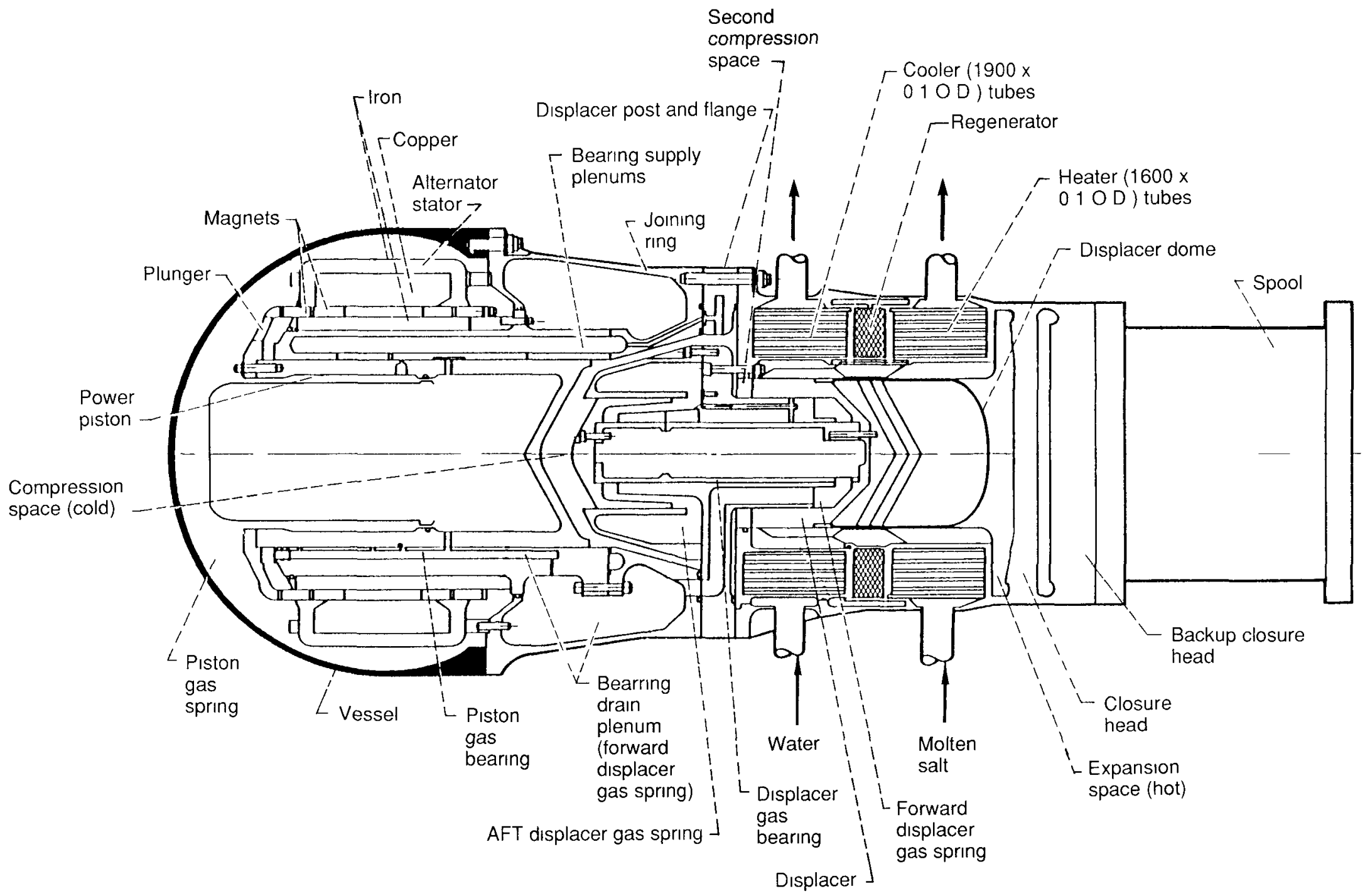

Fig 2 SPRE cross section 


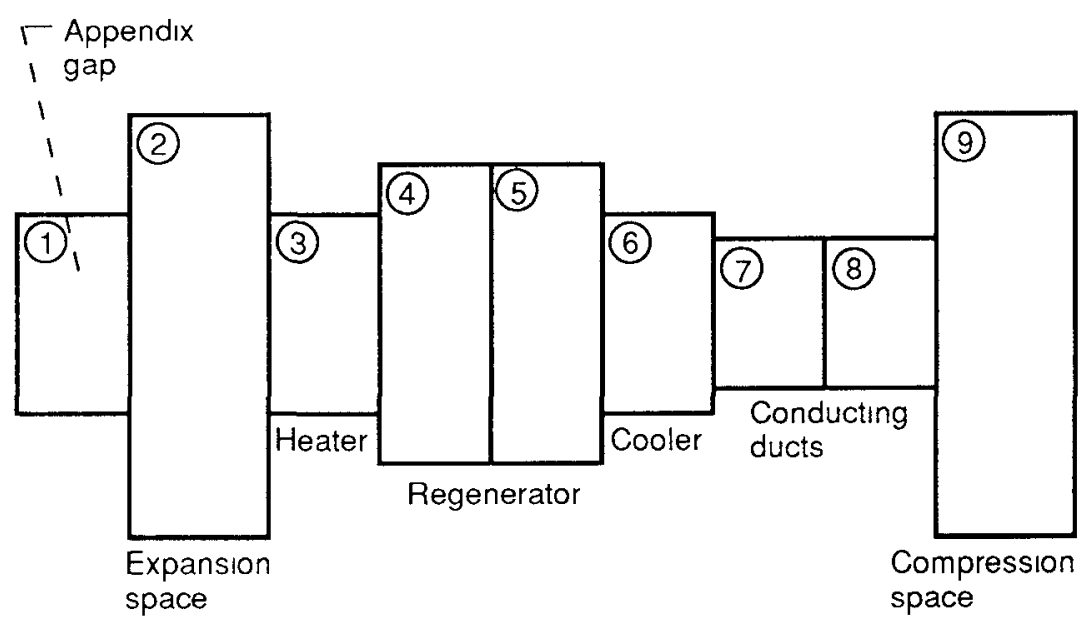

Fig. 3. - Control volumes as a set-up for HFAST computer runs.

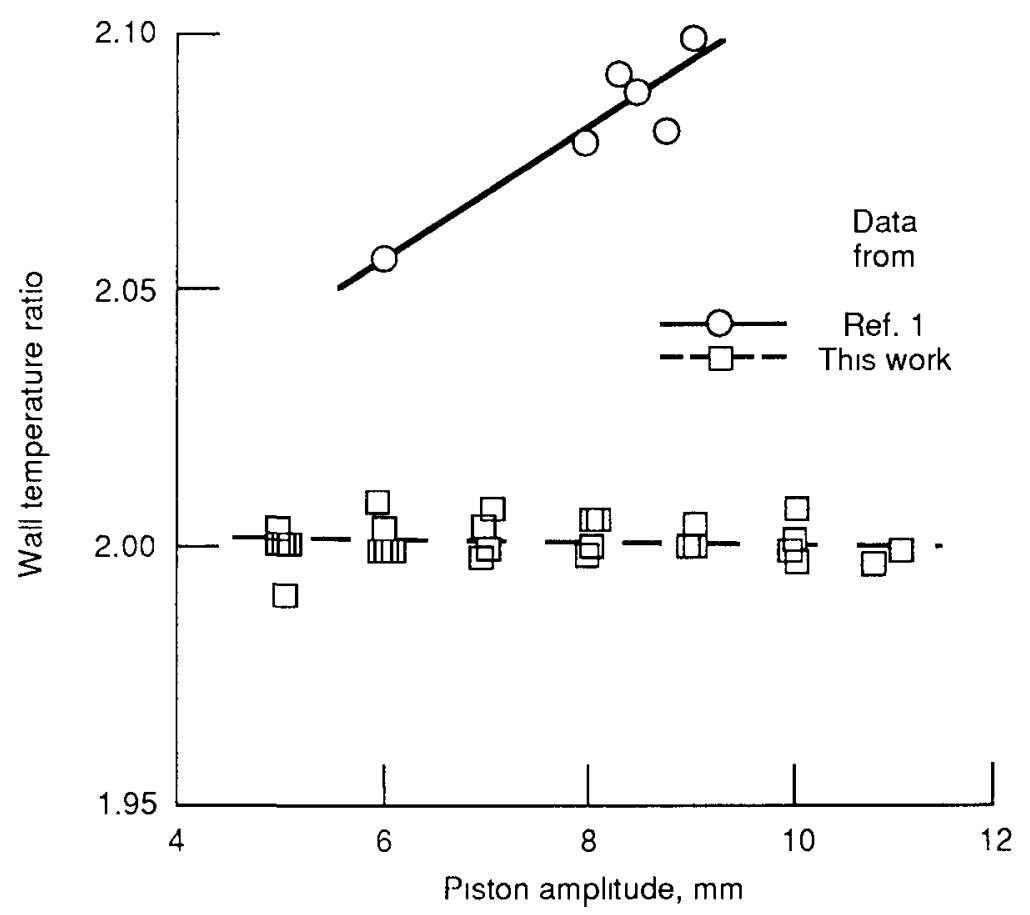

Fig. 4. - Wall temperature ratıo versus piston amplitude 


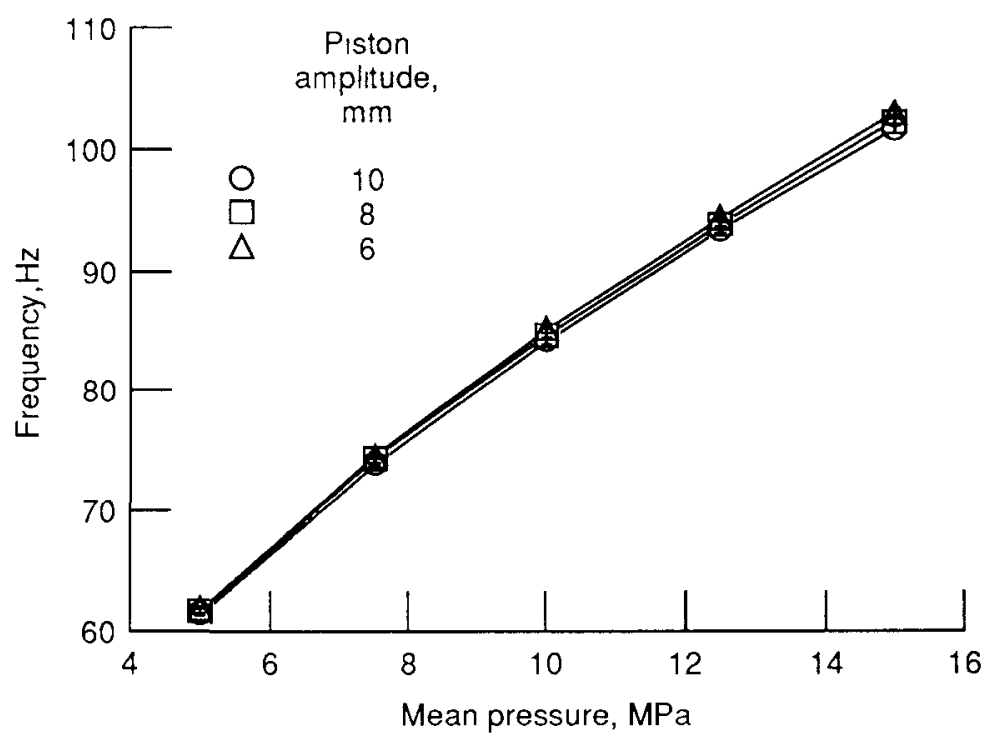

Fig 5 - Frequency versus mean pressure

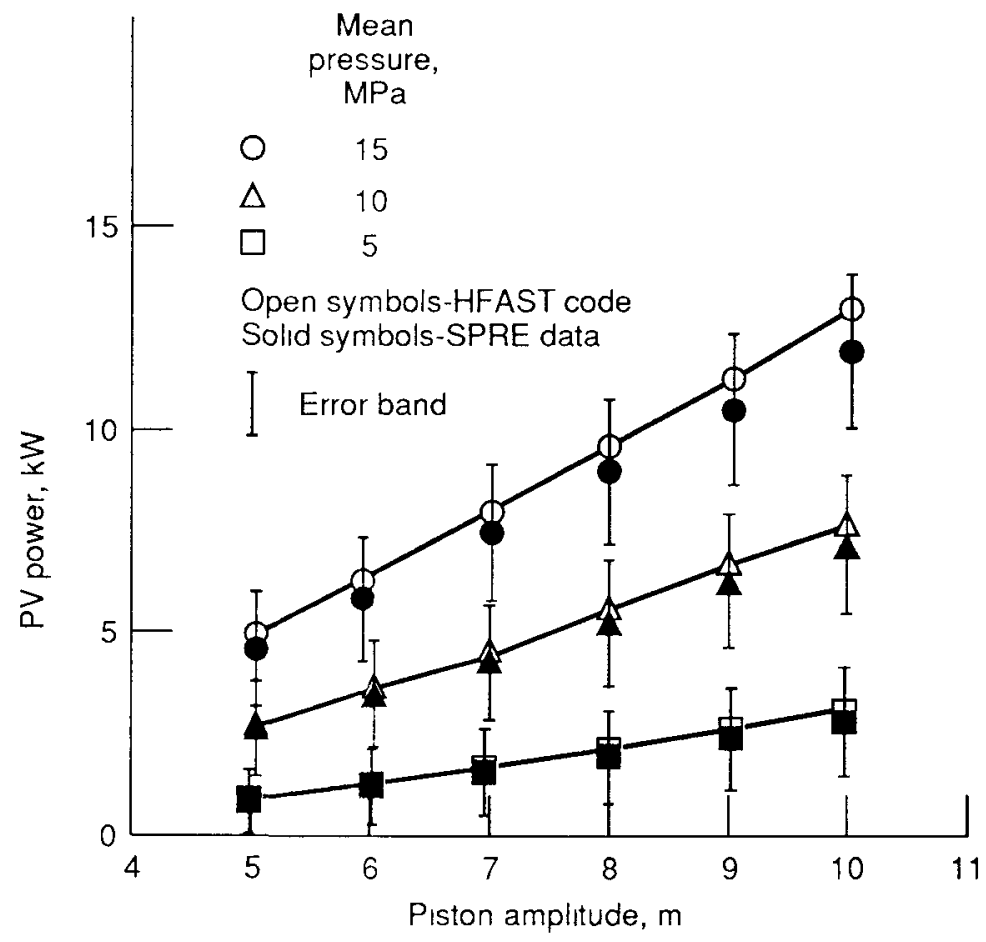

Fig 6 - Piston PV power versus piston amplitude 


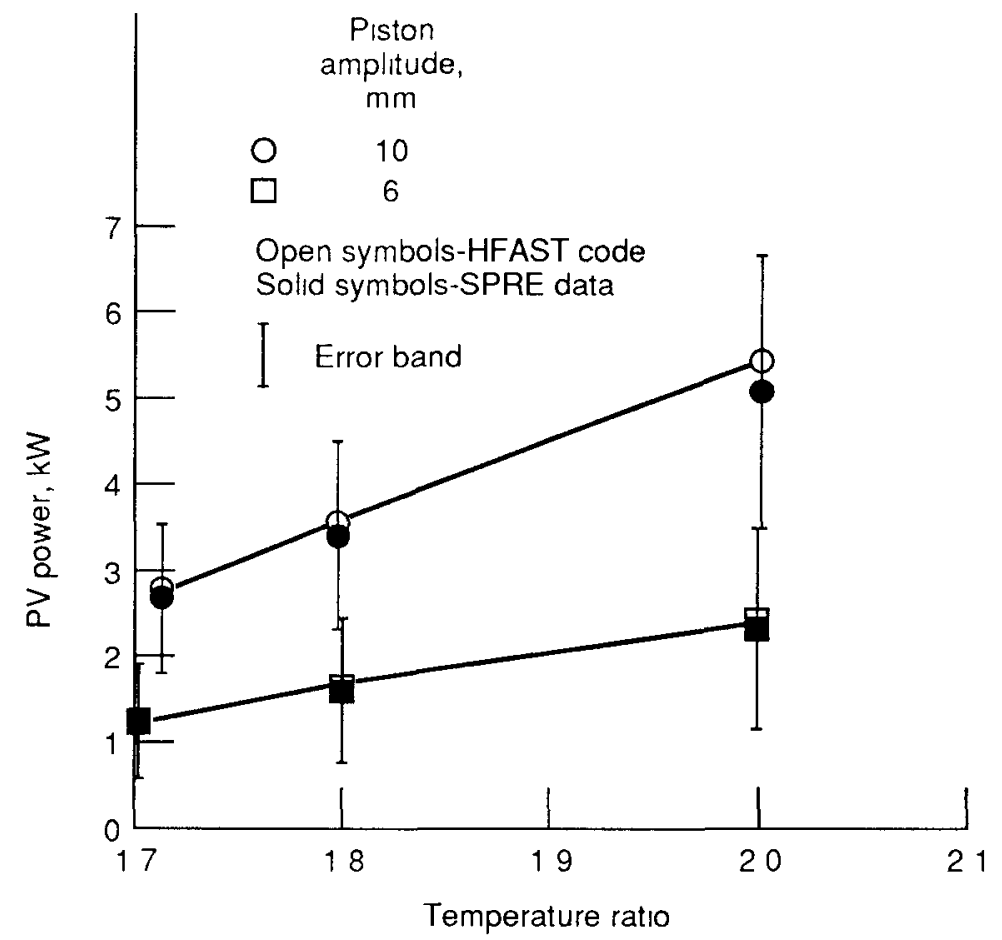

Fig 7 - Piston PV power versus temperature ratıo

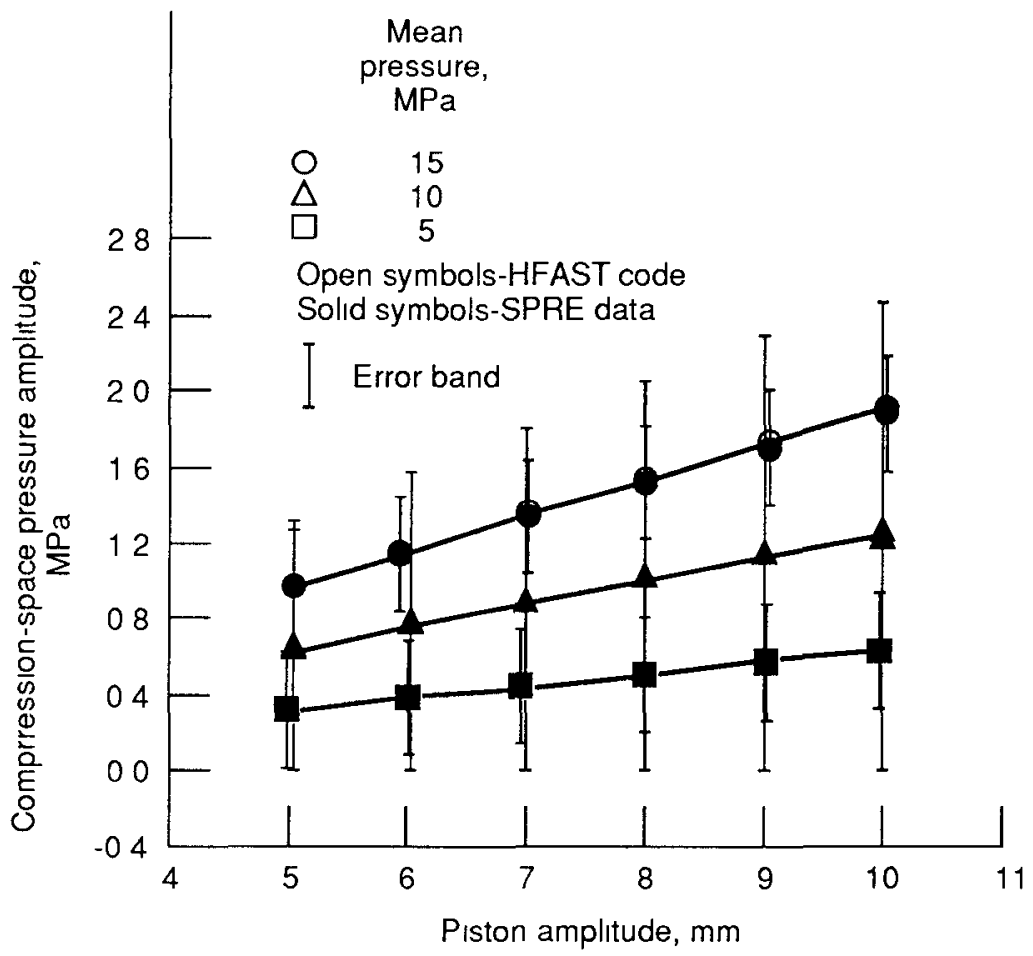

Fig 8 - Compression-space amplitude versus piston amplitude 


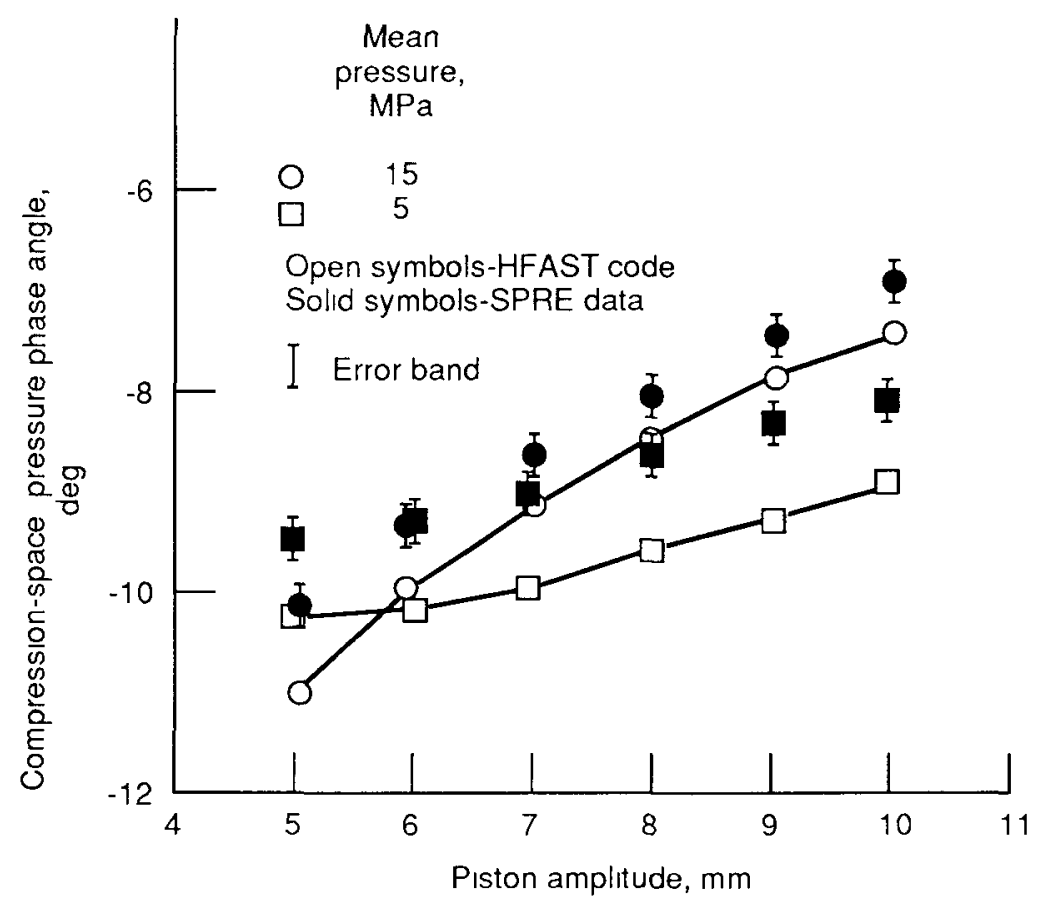

Fig. 9 - Compression-space pressure phase angle versus piston amplitude

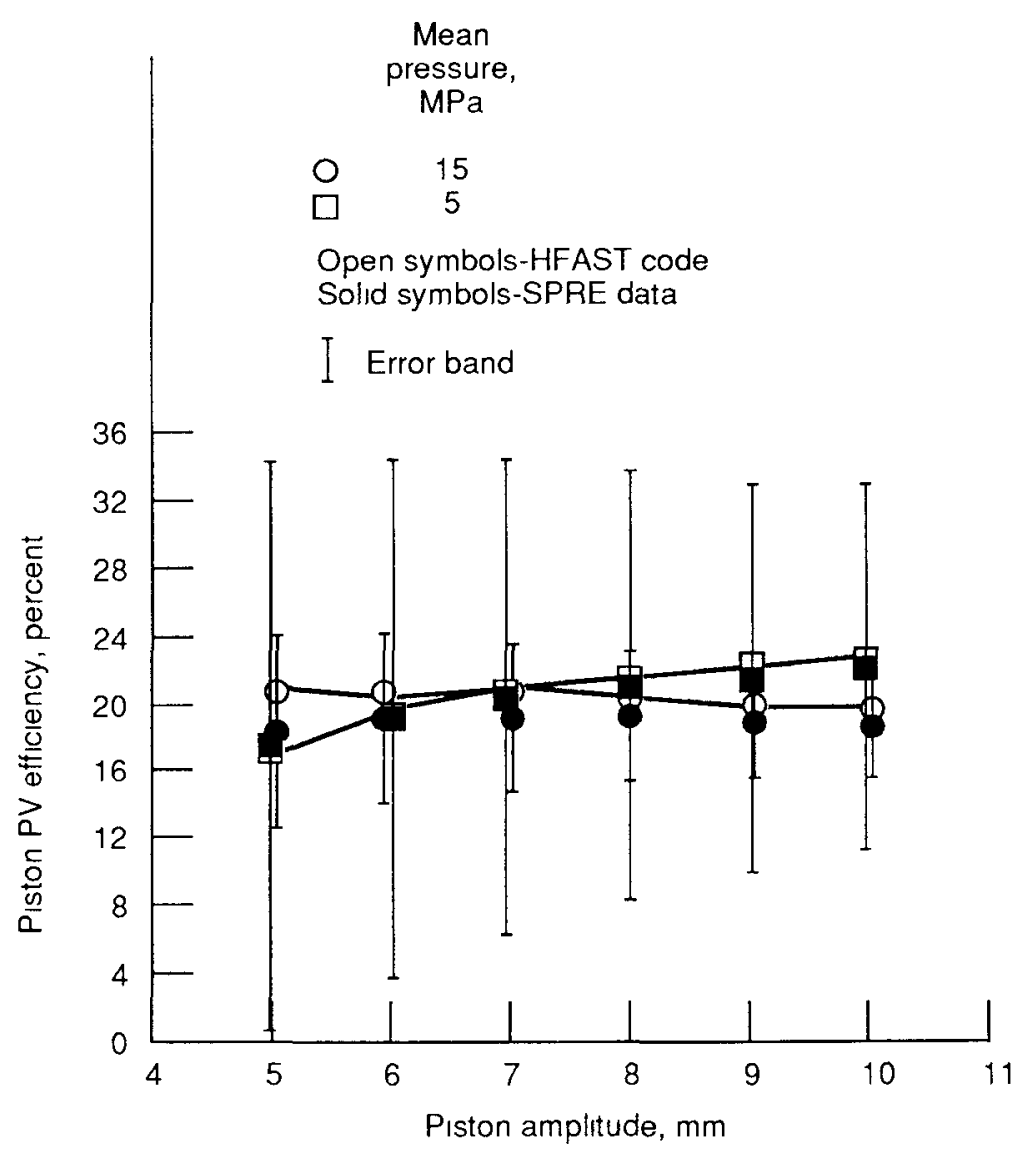

Fig. 10 - Piston PV efficiency versus piston amplitude. 


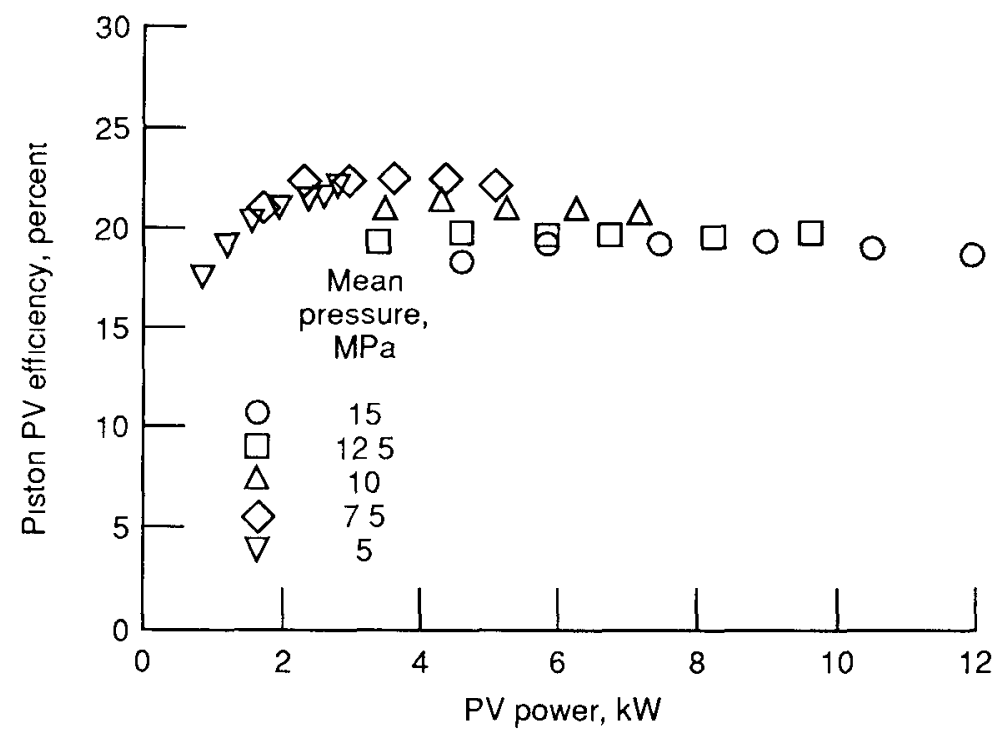

Fig 11 - Piston PV efficiency versus PV power for SPRE data

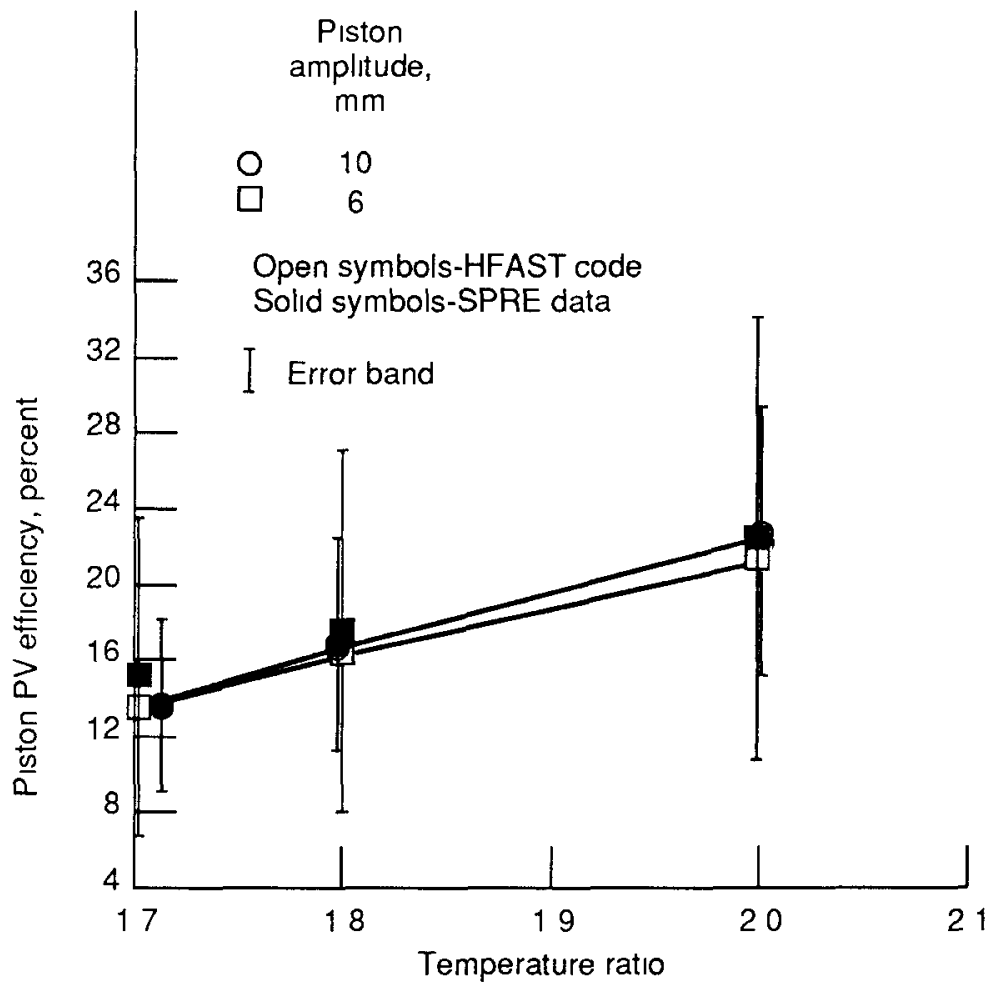

Fig 12 - Piston PV efficiency versus temperature ratio 


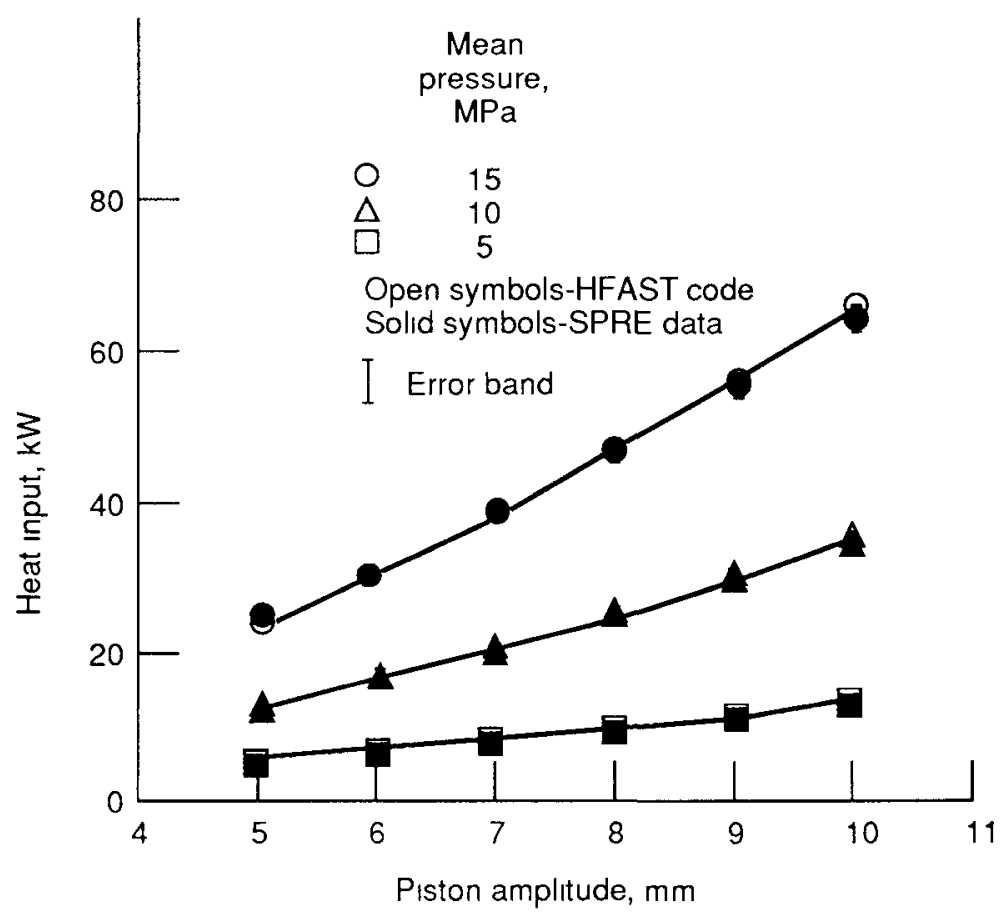

Fig 13 - Heat input versus piston amplitude.

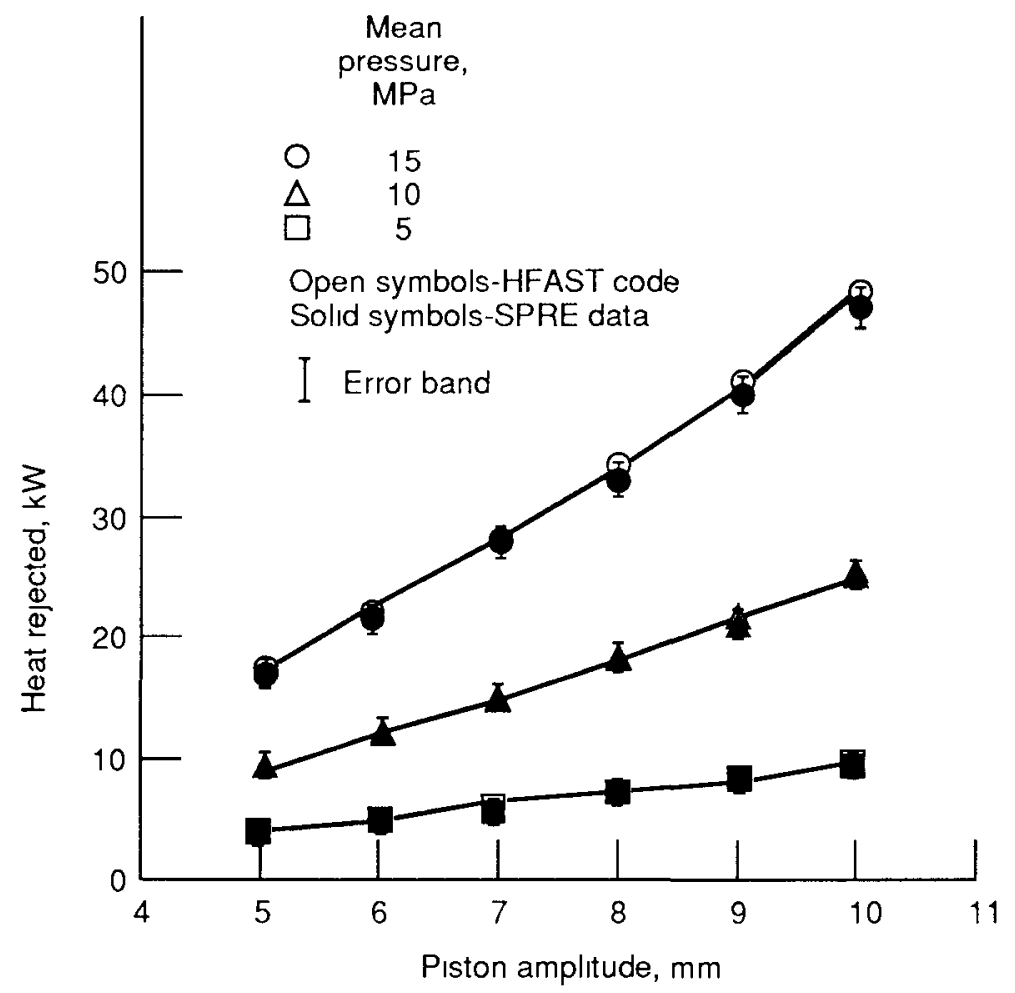

Fig 14. - Heat rejected versus piston amplitude. 


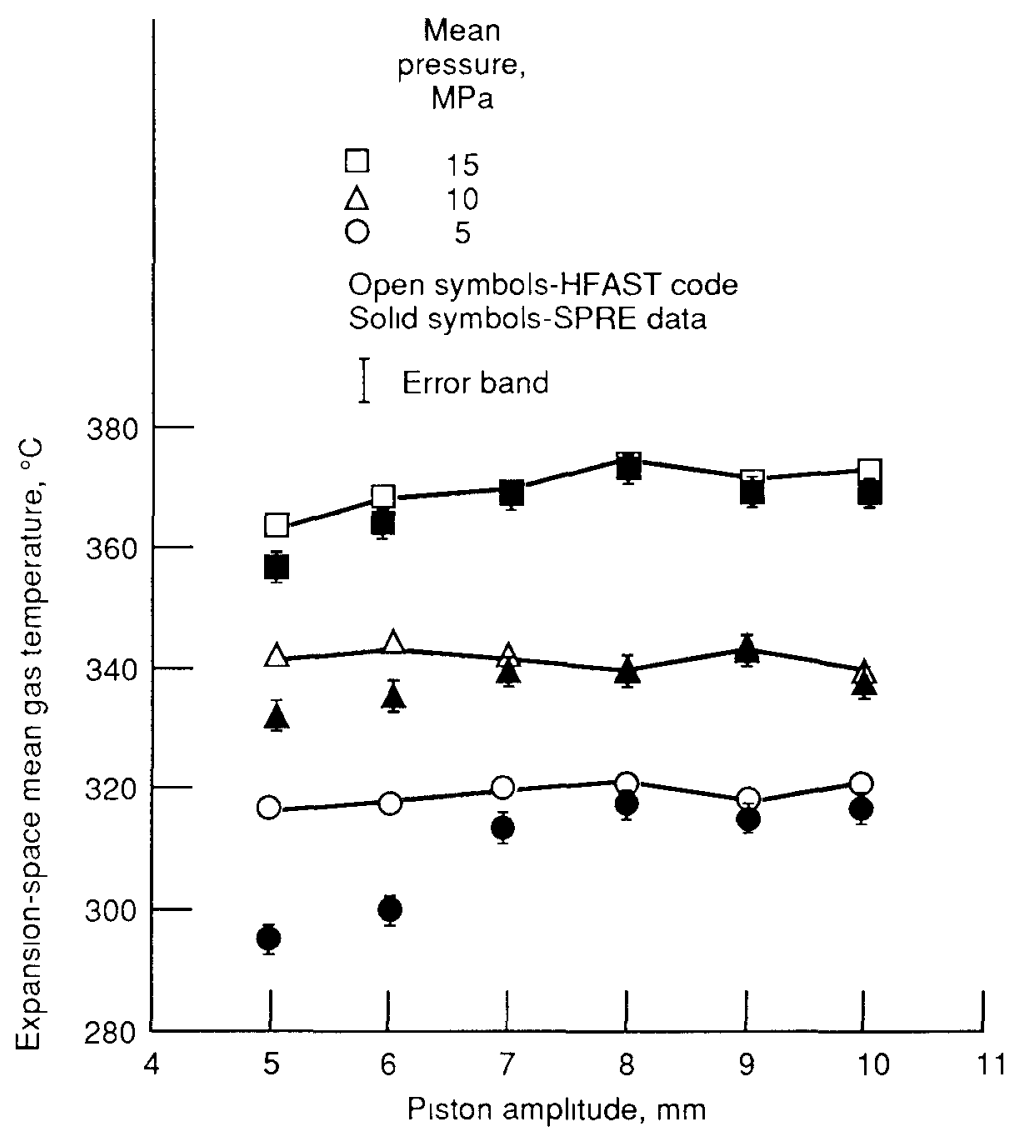

Fig. 15. - Expansion-space mean gas temperature versus piston amplitude

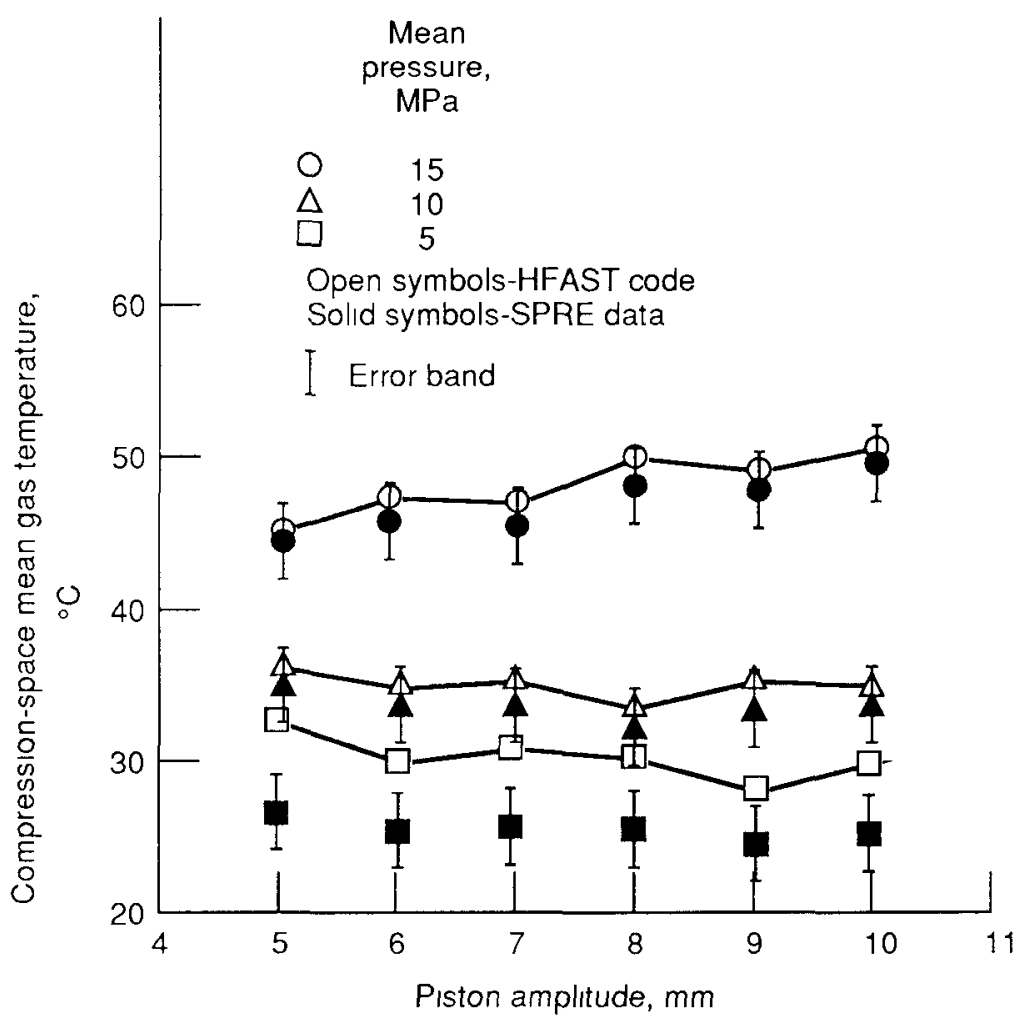

Fig 16. - Compression-space mean gas temperature versus piston amplitude. 


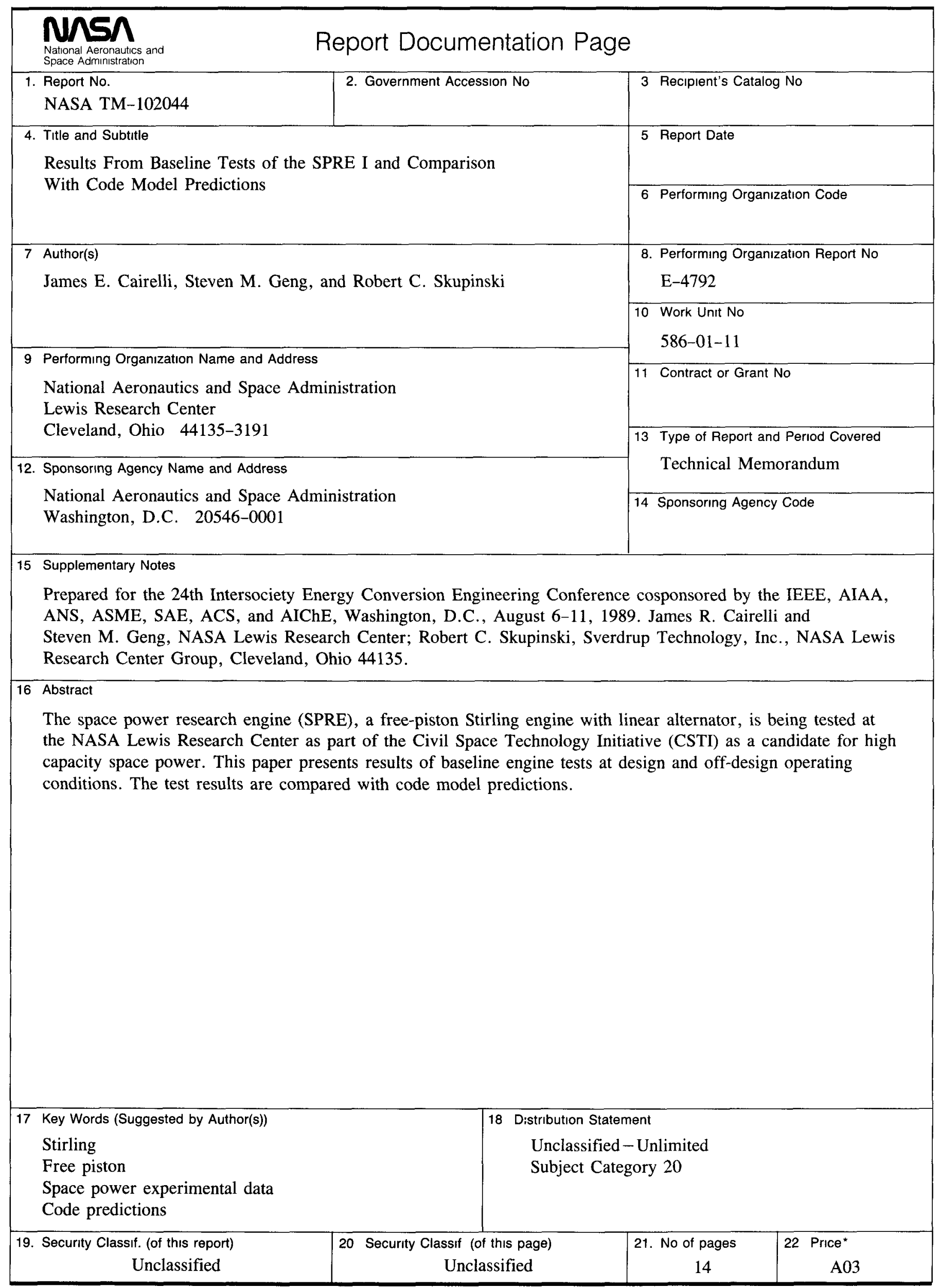


National Aeronautics and

Space Administration

Lewis Research Center

Cleveland, Ohio 44135

\section{Otticial Buaines:}

Penalty for Prlvate Use $\$ 300$

FOURTH CLASS MAIL

ADDRESS CORRECTION REQUESTED

-HWII

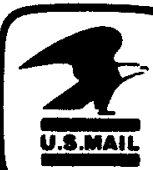

Postage and Fees Paid Natıonal Aeronautics and

Space Admınistration

NASA 451

ANALEX/B . Thompson 301-5 